\title{
THE FIRST HUNGARIAN RECORD OF A RARE GOMPHONEMA (BACILLARIOPHYTA) SPECIES FROM TEMPORARY PONDS
}

\author{
Éva Ács ${ }^{1,2 *}$, Angéla Földi ${ }^{1,3}$, Keve T. KIss ${ }^{1} \&$ Krisztina BuCz Kó ${ }^{1,4}$ \\ ${ }^{1}$ Danube Research Institute, MTA Centre for Ecological Research, \\ H-1113 Budapest, Karolina út 29, Hungary; *Correspondingauthor: acs.eva@okologia.mta.hu \\ ${ }^{2}$ Institute for Sustainable Development Studies, Faculty of Water Sciences, National University of \\ Public Service, H-6500 Baja, Bajcsy-Zsilinszky utca 12-14, Hungary \\ ${ }^{3}$ Doctoral School of Environmental Sciences, Eötvös Loránd University, \\ H-1117 Budapest, Pázmány Péter sétány 1/A, Hungary \\ ${ }^{4}$ Department of Botany, Hungarian Natural History Museum, \\ H-1087 Budapest, Könyves Kálmán krt. 40, Hungary
}

Ács, É., Földi, A., Kiss, K. T. \& Buczkó, K. (2019): The first Hungarian record of a rare Gomphonema (Bacillariophyta) species from temporary ponds. - Studia bot. hung. 50(1): 19-27.

\begin{abstract}
The first record of Gomphonema jadwigiae in Hungary and morphological characteristics of the species (including scanning electron microscope details) are provided. The species was observed in samples taken from some bomb crater ponds situated in the northernmost part of the Kiskunság National Park, near the village of Apaj, in the plain of the Danube-Tisza Interfluve, Central Hungary. Gomphonema jadwigiae occurred in three ponds, and it was dominant in one of them. In its first description the species was regarded as an oligotrophic indicator, but our results suggest that it can tolerate the elevated salinity and nutrient concentration as well.
\end{abstract}

Key words: Gomphonema jadwigiae, bomb crater ponds, salinity

\section{INTRODUCTION}

The diatoms are considered to be useful indicators of environmental changes, and particularly used as indicators of organic pollution and high nutrient loads (SMOL \& STOERMER 2010). The accurate ecological interpretation of their autecological characteristics requires correct identification of the species. This can be particularly difficult task in the case of the genus Gomphonema which has great morphological variation (LeVkOv et al. 2016). They attach to the substrate with branched mucilaginous stalk secreted via apical pore field situated only on foot pole of the frustulum, which is characteristic to this genus. Many Gomphonema species have proved to be important indicators of environmental conditions, but taxa belonging to this genus cannot be identified using solely light microscope, because of the overlapping characteristics (WojTAL 2003). The taxa of the genus 
Gomphonema are cosmopolitan, relatively common in freshwater benthic communities (Wojtal 2003), but some species can tolerate the elevated salinity as well (e.g. G. olivaceum var. calcarea (Cleve) Cleve in Van Heurck (DENYs 1991); G. salinarum (Pantocsek) Cleve (LANGE-BERTALOT \& STEINDORF 1996).

Extreme habitats, like small, sodic bomb crater ponds, even if they are artificial ones, may host unique flora and fauna and contribute over-proportionally to regional biodiversity (VAD et al. 2017). We found a Gomphonema species identified as Gomphonema jadwigiae Lange-Bertalot \& E. Reichardt, which is rare all over the world. The species was described from an Austrian lake near Lermoos in 1996 based on light microscopic investigation without any scanning electron micrographs. Moreover there are not any kind of type material (pers. comm. of authors) for reinvestigation. The species was dominant in bomb crater ponds at Apaj, allowing us to perform a detailed electron microscopic investigation. We have already reported its occurrence from this habitat (e.g. Ács et al. 2017), but without detailed morphological taxonomic description and photo documentation, which is important for e.g. the 'analysts' participating in monitoring programs, especially if a species is dominant in some water bodies.

Our aim is to provide a detailed morphological description of this dominant Gomphonema species using scanning electron microscope (SEM) for demonstrating its first Hungarian occurrence.

\section{MATERIAL AND METHODS}

\section{Study site}

A dense cluster of bomb crater ponds (created by mistargeted bombing of the nearby airport during World War II) is situated in the northernmost part of the Kiskunság National Park $\left(47.12338^{\circ} \mathrm{N}, 19.13645^{\circ} \mathrm{E}\right)$, near the village of Apaj, in the plain of the Danube-Tisza Interfluve, Central Hungary in an area of approximately 25 hectares. This area has patchy surface salinization, because the flow pattern of groundwater results in extensive surface salinization in those discharge areas where the infiltrating freshwater does not superimpose the upwelling saline water (SIMON et al. 2011). The patchy surface salinization results in different salinity of the water of bomb crater ponds here. More information of the study sites is available in VAD et al. (2017).

\section{Sampling}

Altogether 48 ponds were sampled for benthic diatoms. Samples were taken from $10 \mathrm{~cm}$ section (or maximal length if the depth of pond was less than 
$10 \mathrm{~cm}$ ) of the green common reed (Phragmites australis (Cav.) Trin. ex Steud.) stems, or, if it was absent, from alkali bulrush (Bolboschoenus maritimus (L.) Palla) or narrowleaf cattail (Typha angustifolia L.) between 7 and 9 May, 2014. Stems were chosen randomly in five replicates per pond. The following physico-chemical variables were measured in the case of each pond: water depth, diameter of pond, percentages of open water surface, submerged and emergent macrophyte coverage, conductivity, $\mathrm{pH}$, water temperature, turbidity, total suspended solids (TSS), total phosphorous (TP), nitrate $\left(\mathrm{NO}_{3}-\mathrm{N}\right)$, ammonium $\left(\mathrm{NH}_{4}-\mathrm{N}\right)$, chlorophyll-a $(\mathrm{Chl} a)$, calcium $\left(\mathrm{Ca}^{2+}\right)$ and chloride $\left(\mathrm{Cl}^{-}\right)$concentration. The determination methods and more details of sampling are available in VAD et al. (2017).

\section{Microscopic investigations}

The diatom frustules were cleaned with hydrochloric acid and hydrogen peroxide, subsequently washed in distilled water and mounted with Naphrax medium (CEN 2014). An Olympus IX70 inverted microscope equipped with differential interference contrast (DIC) optics was used for LM observations, for the micrographs we used Zeiss Axio Imager Z2 light microscope equipped with Axiocam 506. For SEM studies a part of the cleaned and washed samples was filtered through a $3 \mu \mathrm{m}$ Isopore ${ }^{\mathrm{rx}}$ polycarbonate membrane filter (Merck Millipore), which was fixed onto a stub using double-sided carbon tape, and coated with gold using a rotary-pumped spatter coater Quorum Q150R S. The fine structures of the diatom frustules were observed with Zeiss EVO MA 10 SEM operated at 10 $\mathrm{kV}$ and $10 \mathrm{~mm}$ distance using SE detector.

\section{RESULTS}

Gomphonema jadwigiae occurred only in three ponds (from the 48 studied ones) and it was dominant only in one pond (relative abundance: $8.9 \%$ ). Moreover, sixteen species, including Gomphonema angustatum (Kützing) Rabenhorst, G. productum (Grunow) Lange-Bertalot \& Reichardt, Halamphora dominici Ács \& Levkov, Navicula veneta Kützing, N. wiesneri Lange-Bertalot, Nitzschia austriaca Hustedt, N. reskoi Ács, Duleba, C. E. Wetzel \& Ector, Psammodictyon constrictum (Gregory) D. G. Mann in Round et al., Tryblionella hungarica (Grunow) D. G. Mann in Round et al. were dominant (relative abundance reached $5 \%$ in at least one sample) in those ponds, where G. jadwigiae also occurred. This is the first Hungarian occurrence of G. jadwigiae. The physico-chemical variables of those ponds where G. jadwigiae occurred are in Table 1. 
Gomphonema jadwigiae Lange-Bertalot \& E. Reichardt (LANGE-BERTALOT \& Metzeltin 1996: 70, pl. 98: Figs 11-14)

Description: In the original description, the headpole of the species is shortly rostrate to apiculate. Our specimens are rostrate. The length of the Apaj' population is $27-40 \mu \mathrm{m}$, width at mid-valve is ranging from 7.6 to $9.4 \mu \mathrm{m}(\mathrm{n}=$ 30). Striae run parallel in mid-valve and becoming radiate towards the footpole and headpole (Figs 1-5). Number of striae is $10-14$ in $10 \mu \mathrm{m}$. Axial area is narrow, linear (Figs 1-5). One pore present at the end of long central stria, opposite of it is a shortened stria, composed of 7 externally slit-like, internally rectangular areolae (Figs 7-11). The pore is well distinguishable from the stria, its external opening is small, round shape (Fig. 6), internally slit-like (Fig. 7). The raphe is lateral and slightly undulate with simple, slightly expanded proximal raphe endings (Figs 8-10). External proximal raphe endings are tear-drop shaped and slightly deflected towards the pore (Fig. 6). Distal raphe endings are unilaterally deflected opposite of the pore-bearing side, extending onto the valve mantle (Figs 8-9). Internally the distal raphe endings terminate in a small helictoglossa (Figs 10-11),

Table 1. The values of the environmental variables recorded for those bomb crater ponds where G. jadwigiae occurred.

\begin{tabular}{|c|c|c|c|}
\hline Pond $\mathrm{N}^{\circ}$ & 10 & 42 & 69 \\
\hline Area $\left(\mathrm{m}^{2}\right)$ & 28.3 & 28.3 & 38.5 \\
\hline Depth $(\mathrm{cm})$ & 50 & 31 & 44 \\
\hline Salinity $\left(\mathrm{g} \mathrm{L}^{-1}\right)$ & 2.8 & 2.8 & 2.5 \\
\hline Conductivity $\left(\mathrm{mS} \mathrm{cm}^{-1}\right)$ & 3.7 & 3.7 & 3.3 \\
\hline $\mathrm{pH}$ & 8.5 & 8.7 & 8.7 \\
\hline Secchi-depth $(\mathrm{cm})$ & 27.0 & 9.0 & 10.0 \\
\hline Turbidity (NTU) & 34 & 104.0 & 128.0 \\
\hline Total suspended solids $\left(\mathrm{mg} \mathrm{L}^{-1}\right)$ & 26.6 & 54.3 & 106.0 \\
\hline Total phosphorus $\left(\mu \mathrm{g} \mathrm{L}^{-1}\right)$ & 124.8 & 138.5 & 533.5 \\
\hline Chlorophyll- $a\left(\mu \mathrm{g} \mathrm{L}^{-1}\right)$ & 9.1 & 9.8 & 4.1 \\
\hline Nitrate nitrogen $\left(\mathrm{mg} \mathrm{L}^{-1}\right)$ & 0.73 & 0.23 & 0.34 \\
\hline Ammonium nitrogen $\left(\mathrm{mg} \mathrm{L}^{-1}\right)$ & 0.06 & 0.09 & 0.13 \\
\hline Chloride $\left(\mathrm{mg} \mathrm{L}^{-1}\right)$ & 553.5 & 354.2 & 362.5 \\
\hline Calcium $\left(\mathrm{mg} \mathrm{L}^{-1}\right)$ & 155.6 & 10.8 & 20.2 \\
\hline Open water surface (\%) & 97 & 90 & 95 \\
\hline Submerged macrophyte coverage (\%) & 0 & 0 & 0 \\
\hline Emergent macrophyte coverage (\%) & 3 & 10 & 5 \\
\hline
\end{tabular}



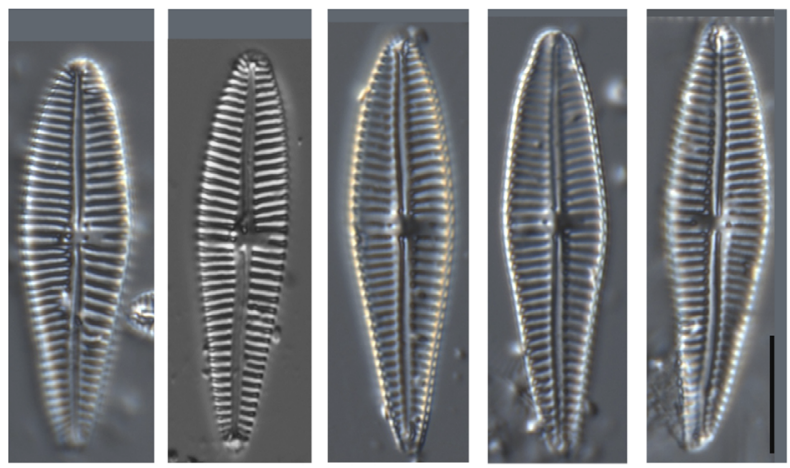

$1-5$

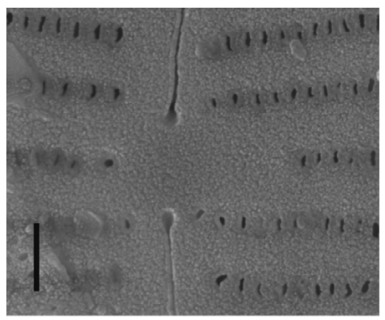

6
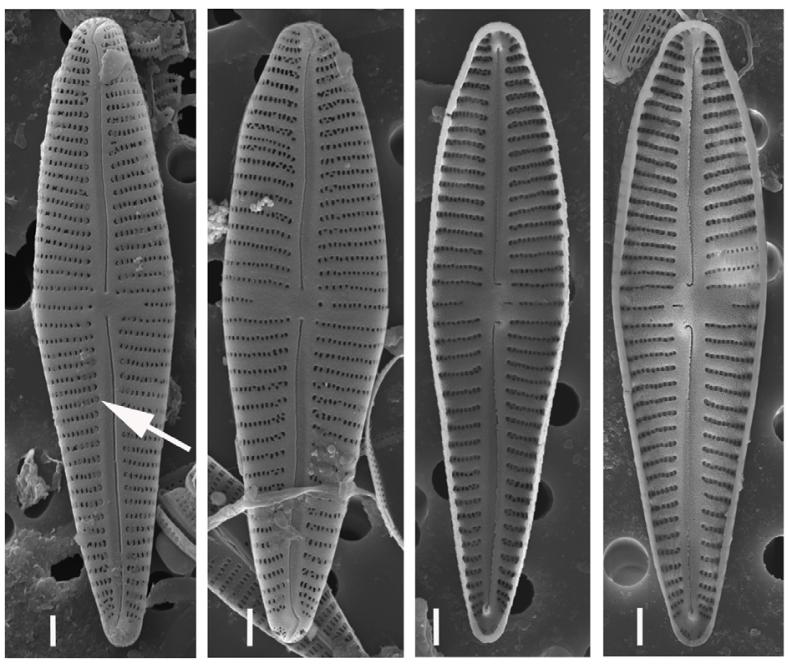

$8-11$

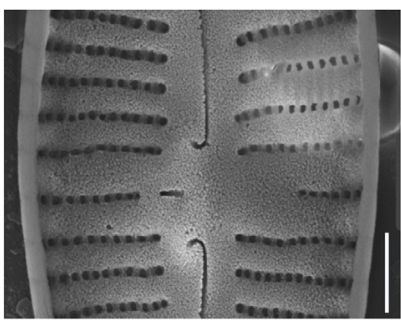

7

Figs 1-11. Gomphonema jadwigiae. - Figs 1-5: Valve face in LM. Fig. 6: Central area with round pore. Outside view SEM. Fig. 7: Central area with slit-like pore. Inside view SEM. Note the unilaterally curved hook-shaped raphe endings. Figs 8-9: Valve outside view SEM. Note the slit-like areolae becoming c-like near the raphe (arrow). Figs 10-11: Valve inside view SEM. Scale bars = $10 \mu \mathrm{m}$ (Figs 1-5), scale bars $=2 \mu \mathrm{m}$ (Figs 7-11), scale bar $=1 \mu \mathrm{m}$ (Fig. 6). 
the proximal raphe endings are hook-shaped, curved towards the pore-bearing side (Fig. 7). The foot pole has a typical differentiated apical pore field with porelli, separated from striae by a hyaline area, and divided into two parts by the raphe (Figs 8-11). Externally the striae are composed of slit-like areolae becoming c-like near the raphe (Figs 8-9).

\section{DISCUSSION}

The studied bomb crater ponds are regarded as an excellent ecological model system (VAD et al. 2017) which allows us to get knowledge about the structure of the diatom communities inhabiting intermittent waters having different salinity, caused by the varying width of the macrophyte belt surrounding the ponds (FöLDI et al. 2018). The pond-system maintains high beta-diversity, which has nature conservation importance (VAD et al. 2017).

The species of the genus Gomphonema are relatively common in freshwater benthic communities (Wojtal 2003), but are not so typical for saline environments. For example in the reviews of Central European soda pans, the authors reported on the presence of only a few Gomphonema species (STENGER-Kovács \& LENGYEL 2015, STENGER-KovÁcs et al. 2018). However, as we mentioned earlier, diatom communities of these bomb crater ponds showed high similarity to those of natural astatic soda pans belonging to the biological type 3 according to the Hungarian typology (Föld et al. 2018, VAD et al. 2017), but Gomphonema jadwigiae has not been found yet in these pans. The species resembles Gomphonema angustatum (Kütz.) Rabenhorst, which was also dominant in our samples, but the structure of areolae and the internal view of pore clearly distinguish them in SEM. G. angustatum has c-like areolae and internally the pore is round, while $G$. jadwigiae has slit-like areolae becoming c-like near the raphe and internally the pore is slit-like. Furthermore, G. jadwigiae resembles Gomphonema latelanceolatum Levkov, Mitic-Kopanja \& E. Reichardt as well, but the areolae of the latter are covered by siliceous flap (LEV Kov et al. 2016).

Gomphonema jadwigiae was described as an oligotrophic indicator in 1996 (LAnge-Bertalot \& Metzeltin 1996). Our specimens are less capitate than the type ones (see T65 Figs 20-21 and T98 Figs 11-14 in LANGE-BERTALOT \& Metzeltin 1996). Because no raw material is available (pers. comm. of LangeBertalot and Reichardt) for SEM studies, in 2016 we collected samples from the type locality, but unfortunately we could not find the species in the samples. So for the correct identification of the species found in Apaj we used the micrographs published in LEVKOV et al. (2016). The only difference is the less capitate headpole of the Apaj' population, however some specimens of the Macedonian population also have no capitate end (see P81 Figs 2-5 and P82 Fig. 1 in Lev Kov 
et al. 2016). So we consider that our species is identical to Levkov's one published as G. jadwigiae (LEVKov et al. 2016).

This is the first Hungarian occurrence of Gomphonema jadwigiae. We found it in three hypertrophic bomb crater ponds (the total phosphorus concentration in these ponds was above $100 \mu \mathrm{g} \mathrm{L}^{-1}$, which is the limit of hypertrophic conditions according to the OECD 1982). G. jadwigiae is a worldwide rare species. It was noted as an 'interesting record' in the monitoring of benthic diatoms of lakes in Brandenburg (WERNER 2014). Moreover, it has been found in the Nielba River (Poland) (Messyasz et al. 2011), in the eutrophic Lake Dojran and the Vardar River, Macedonia (LEvkov et al. 2016), in a meso-eutrophic-eutrophic pond (Orangery lake) of the Botanical Garden Meise (Belgium) (Foets 2016), in a mesotrophic lake in Russia (Lake Glubokoye near Moskow) (CsudAjev \& Gololobova 2016), in the eutrophic Lake Villadangos (southeast León, northwest Spain) (BLANCo et al. 2017), and in two small rivers of Hainan Island (China) (ZHI-XIN et al. 2018). Except in Nielba River, Lake Villadangos, and our population, the species was not dominant in the samples. Our findings broaden and clarify our knowledge of the indications as well. Because Gomphonema jadwigiae recently occurred mainly in eutrophic habitats, we do not think that it is an oligotrophic indicator species as it was regarded in the first description. The species can tolerate the elevated salinity and nutrient concentration.

\section{CONCLUSIONS}

Extreme habitats, like small, sodic bomb crater ponds, even if they are artificial ones, may host rarely occurring biota and contribute to the maintenance of biodiversity. This finding is an important message for habitat management and nature conservation. Moreover, our findings broaden and clarify our knowledge of the indications. On the basis of our results we do not think that Gomphonema jadwigiae is an oligotrophic indicator as it was regarded in the first description, because this species can tolerate the elevated salinity and nutrient concentration as well. Our results confirm the benefit of SEM for verifying the identity of diatoms, even if it is relatively of large-size, especially for routine monitoring allowing more precise ecological assessment.

Acknowledgements - The authors thanks to Dr Eugen Rott for sampling at the type locality. The authors thank Dr Csaba Ferenc Vad for the original idea to study the biodiversity of bomb crater ponds and organize the first sampling campaigns including the collection of environmental variables we used in the present study. This research was supported by the National Research, Development and Innovation Office - NKFIH 119208 grant. 
Összefoglaló: A Gomphonema jadwigiae Lange-Bertalot \& E. Reichardt fajt az ausztriai Lermoos-hoz közeli tóból írták le 1996-ban, fénymikroszkópos morfológiai bélyegek alapján, a fajról csak ilyen képeket közölve. Ezt a kovaalgát a Kiskunsági Nemzeti Park területén, Apaj község határában található bombatölcsérekben kialakult hipertróf (az OECD 1982 által kidolgozott 100 $\mu \mathrm{g} \mathrm{L}{ }^{-1}$ összes foszfor határérték feletti) szikes tavakban találtuk meg (egyikben dominánsként is), mely a faj eddig ismert egyetlen hazai előfordulási helye, de világszerte is kevés helyről került eddig elő. A rendelkezésre álló határozókönyvek és irodalom alapján a fajt G. jadwigiae-ként azonosítottuk. Ugyanakkor feltűnő volt, hogy az apaji populáció kevésbé fejecskés kovahéjjal rendelkezik, mint a típuspopuláció, azonban LE KOV et al. (2016) határozókönyvében szintén láthatóak az apaji populációhoz hasonlóan kevéssé fejecskés példányok az ott közölt macedón populációban. Mivel típusanyag nem állt rendelkezésre, mintát vettünk a faj típuslelőhelyéről. Azonban a mintából sajnos nem került elő a G. jadwigiae, így a LeVkov et al. (2016) határozókönyvében leírtakra tudtunk csak támaszkodni; az ott közölt finomszerkezeti leírással, fény- és elektronmikroszkópos képekkel hasonlítottuk össze a populációnkat, melyet szintén fény- és elektronmikroszkóppal is vizsgáltunk. Habár fénymikroszkópban emlékeztet a Gomphonema angustatum-ra (amelyik szintén domináns volt a vizsgált bombatölcsérekben) és a Gomphonema latelanceolatum-ra, de elektronmikroszkóppal egyértelmủen meg lehet különböztetni tőlük, elsősorban az areola-szerkezet alapján. Ez egyben felhívja a figyelmet az elektronmikroszkóp használatának a fontosságára még ilyen relatíve nagyméretű faj esetében is, hiszen számos esetben az azonosítás csak a finomszerkezet alapján tehető meg megbízhatóan. A pontos taxonómiai identifikációnak nagy jelentősége van az ökológiai állapotértékelésben is, különösen, ha egy faj domináns a mintában.

Az általunk vizsgált populáció jó egyezést mutat a LeVKov et al. (2016) által publikált $G$. jadwigiae-val. A fajt eredetileg oligotróf indikátorként írták le, azonban sem a többi előfordulási adata, sem az apaji populáció élőhelyének kémiai jellemzői nem támasztják alá ezt az indikációs tulajdonságot. Eredményeink alapján úgy gondoljuk, hogy a faj képes tolerálni az emelkedettebb só- és tápanyag-koncentrációt is.

\section{REFERENCES}

Ács É., Földi A., Wetzel C. E., Vad Cs. F., Kiss K. T., Dobosy P., Trábert Zs., Grigorszky I., ENGLONer A. \& Ector L. (2017): Nitzschia austriaca Hustedt: a characteristic diatom of Hungarian inland saline waters including a morphological comparison with the type material. - Phytotaxa 308(1): 54-65. https://doi.org/10.11646/phytotaxa.308.1.4.

Blanco S., Borrego-Ramos M. \& Olenici A. (2017): Disentangling diatom species complexes: does morphometry suffice? - PeerJ 5: e4159. https://doi.org/10.7717/peerj.4159

CEN (2014): Water quality - guidance for the routine sampling and preparation of benthic diatoms from rivers and lakes. EN 13946: 2014. Comité Européen de Normalisation, Bruxelles, 14 pp.

Csudajev D. A. \& Gololobova M. A. (2016): Diatomovüe Vodoroszlij ozeroa Glubokovo (Moszkovszkaja oblaszty). - Galleja print, Moskow, $447 \mathrm{pp}$.

Denys L. (1991): Introduction, ecological code and complete list. - In: Furse M. T., Hering D., Brabec K., Buffagni A., Sandin L., Verdonschot P. F. M. (eds): A check-list of the diatoms in the Holocene deposits of the Western Belgian coastal plain with a survey of their apparent ecological requirements. Ministére des Affaires Economiques, Service Géologique de Belgique, pp. 1-19.

Foets J. (2016): Paleo-ecologie en jaarcyclus van diatomeeëngemeenschappen en waterkwaliteit van twee vijvers in de Plantentuin Meise. - manuscript, Master Thesis. Antwerpen, 102 pp. 
Földi A., Ács É., Grigorszky I., Ector L., Wetzel C. E., VÁrbíró G., Kiss K. T., Dobosy P., TRÁBERT Zs., Borsodi K. A. \& Duleba M. (2018): Unexpected consequences of bombing. Community level response of epiphytic diatoms to environmental stress in a saline bomb crater pond area. - PLoS ONE 13(10): e0205343. https://doi.org/10.1371/journal.pone.0205343

LANGE-BERTALOT H. \& MeTzeLTin D. (1996): Indicators of oligotrophy. 800 taxa representative of three ecologically distinct lake types, carbonate buffered - oligodystrophic - weakly buffered soft water. - In: Iconographia Diatomologica. Vol. 2. Koeltz Scientific Books, Königstein, 390 pp.

LANGE-Bertalot H. \& STEINdorf A. (1996): Rote Liste der Limnischen Kieselalgen (Bacillariophyceae) Deutschlands. - Schrift. Vegetationsk. 28: 633-677.

Levkov Z., Mitic-Kopanja D. \& Reichardt E. (2016): The diatom genus Gomphonema in the Republic of Macedonia. - In: LANGe-Bertalot H. (ed.): Diatoms of Europe. Diatoms of the European inland waters and comparable habitats. Vol. 8. Koeltz Botanical Books, Oberreifenberg, $552 \mathrm{pp}$.

Messyasz B., Rybak A. S. \& SUChinska A. (2011): Structural response of microscopic algae to Ulva mass appearance in inland waters. - Posters, European Journal of Phycology 46(suppl. 1): 11-18. https://doi.org/10.1080/09670262.2011.613163

OECD (1982): Eutrophication of waters. Monitoring, assessement and control. - OECD, Paris, 154 pp. https://doi.org/10.1002/iroh.19840690206

Simon S., MÁdL-Szönyi J., MÜLler I. \& PogÁcsÁs G. (2011): Conceptual model for surface salinization in an overpressured and a superimposed gravity-flow field, Lake Kelemenszék area, Hungary. - Hydrogeol. J. 19(3): 701-717. https://doi.org/10.1007/s10040-011-0711-8

SMOL J. P. \& STOERMER E. F. (2010): The diatoms: applications for the environmental and earth sciences. - Cambridge University Press, Cambridge, 482 pp.

STENGer-Kovács Cs. \& Lengyel E. (2015): Taxonomical and distribution guide of diatoms in soda pans of Central Europe. - Studia bot. hung. 46: 3-203.

https://doi.org/10.17110/StudBot.2015.46.Suppl.3

Stenger-Kovács Cs., Körmendi K., Lengyel E., Abonyi A., Hajnal É., Szabó B., Buczkó K. \& PADIsÁK J. (2018): Expanding the trait-based concept of benthic diatoms: development of trait and species-based indices for conductivity as the master variable of ecological status in continental saline lakes. - Ecol. Indic. 95: 63-74. https://doi.org/10.1016/j.ecolind.2018.07.026

Vad Cs. F., Péntek A. L., Cozma N. J., Földi A., Tóth A., Tóth B., Böde N. A., Móra A., PtacNik R., Ács É., Zsuga K. \& HoRváth Zs. (2017): Wartime scars or reservoirs of biodiversity? The value of bomb crater ponds in aquatic conservation. - Biol. Conserv. 209: 253-262. https://doi.org/10.1016/j.biocon.2017.02.025

WeRNER P. (2014): Monitoring der benthischen Diatomeenflora zur Indikation des ökologischen Zustandes gemäß EU-Wasserrahmenrichtlinie in 21 Seen des Landes Brandenburg im Jahr 2013. Los 2 Südbrandenburg. - Werkvertrag Nr.: S3-VG-13-023/2, 33 pp.

Wojtal A. (2003): Diatoms of the genus Gomphonema Ehr. (Bacillariophyceae) from a karstic stream int he Krakowsko-Czestochowska upland. - Acta Soc. Bot. Pol. 72(3): 213-220.

Zhi-Xin F., Jia-Jun Z., YAN L. \& YA-Wen F. (2018): Newly recorded species of Gomphonema (Bacillariophyta) from Hainan Island, China. - Plant Sci. J. 36(1): 17-23.

https://doi.org/10.11913/PSJ.2095-0837.2018.10017

(submitted: 06.12.2018, accepted: 27.05.2019) 